\title{
KEBIJAKAN PEMBELAJARAN TEMATIK INTEGRATIF DALAM KURIKULUM 2013 PAUD
}

\author{
Oleh: Aris Nurlailiyah \& Atik Wartini
}
Staf Pengajar di Sekolah Alam Kamulan Yogyakarta
Mahasiswi PGRA Pascasarjana UIN Sunan Kalijaga
Yogyakarta

Email: Atikwartini_asy@yahoo.com

\begin{abstract}
Abstrak
Paper ini adalah kajian yang berbasis library research. Paper ini mencoba mengkaji tentang Kebijakan Pembelajaran Tematik Integratif dalam Kurikulum 2013 PAUD. Paper ini sangat menarik karena, pertama pemerintah telah menetapkan kebijakan pembelajaran tematik integratif, sedangkan di PAUD selama ini sudah menggunakan pendekatan tematik. Kedua, pendekatan pembelajaran tematik integratif menjadi hal utama dalam penggunaan K-13 PAUD dibandingkan dengan pendekatan pembelajaran lain. Pada paper ini terdapat tiga pertanyaan, yaitu pertama bagaimana kebijakan K-13 PAUD?, kedua, bagaimana pendekatan pembelajaran berbasis K-13, ketiga bagaimana implementasi tematik Integratif di PAUD?. Tujuan dari kajian ini adalah untuk mengetahui kebijakan K-13 PAUD, pendekatan pembelajaran K-13 PAUD dan implementasi tematik integratif. Kesimpulan dari paper ini, yang pertama Kebijakan pembelajaran tematik integratif berdasarkan landasan yuridis, psikologis dan filosofis. Kedua Pendekatan pembelajaran K-13 PAUD yang utama adalah tematik integratif dan yang ke tiga implementasi pembelajaran tematik integratif mengacu pada kebijakan K-13 PAUD sebagai acuan minimal dengan akhir dari kegiatan pembelajaran terdapat puncak tema.
\end{abstract}

Kata Kunci :Tematik, Integratif, PAUD. 


\section{A. Pendahuluan}

Kurikulum bisa dikatakan sebagai jantungnya pendidikan karena merupakan sebuah program belajar bagi anak untuk mencapai tujuan tertentu. Sedangkan dalam Undang-undang No. 20 Tahun 2003 tentang sistem Pendidikan Nasional pasal 1 ayat 19, Kurikulum diartikan seperangkat rencana dan pengaturan mengenai tujuan, isi dan bahan pelajaran serta cara yang digunakan sebagai pedoman penyelenggaraan kegiatan pembelajaran untuk mencapai tujuan pendidikan tertentu. Lebih lanjut pada pada ayat 3 disebutkan bahwa kurikulum disusun sesuai dengan jenjang pendidikan dan jenis pendidikan dalam kerangka Negara kesatuan Republik Indonesia dengan memperhatikan peningkatan iman dan taqwa, peningkatan akhlak mulia, peningkatan potensi, kecerdasan dan minat peserta didik, keragaman potensi daerah dan lingkungan, tuntunan pembangunan daerah dan nasional, tuntutan dunia kerja, perkembangan ilmu pengetahuan teknologi dan seni, agama, dinamika perkembangan global, persatuan nasional dan nilainilai kebangsaan. ${ }^{1}$

Kebijakan kurikulum dalam implementasinya tentunya memerlukan beberapa pendekatan pembelajaran agar tujuan pembelajaran tercapai. Selain itu dengan memperhatikan tingkatan mutu agar menjadi manusia yang seutuhnya dan tuntutan perkembangan Dunia. Oleh karena itu, dirasa perlu adanya kebijakan pembelajaran yang terintegrasi sehingga pembelajaran tidak berdiri sendiri-sendiri dan kegiatan belajar tidak menjadi beban anak tetapi menjadi taman untuk anak. Oleh karena itu, integrasi menjadi suatu hal yang urgen agar

\footnotetext{
${ }^{1}$ Undang-Undang No. 20 Tahun 2003 tentang sistem Pendidikan Nasional.
} 
pembelajaran lebih bermakna karena melibatkan beberapa bidang pengembangan aspek dan ilmu. Hal ini berarti setiap subjek pembelajaran memiliki keterkaitan yang erat sehingga perlu sistem pembelajaran tematik. ${ }^{2}$

Pendekatan dalam kurikulum 2013 Pendidikan Anak Usia Dini (PAUD) terdiri dari pendekatan; (1) Tematik Integratif, (2) Saintifik, (3) Bermain Kreatif, dan (4) Kecerdasan jamak. Dalam hal ini tematik integratif dan saintifik merupakan pendektan utama yang harus digunakan dalam pengembangan kegiatan belajar melalui bermain terutama bagi anak usia 3-4 tahun dan anak usia 4-6 tahun di lembaga PAUD. ${ }^{3}$ Selanjutnya ada pilihan alternatif dalam pengembangan kegiatan melalui bermain, yaitu pendekatan bermain kreatif dan kecerdasan jamak. Pada paper ini akan membahas lebih lanjut tentang pembelajaran tematik integratif dalam K-13 PAUD.

\section{B. Pembahasan}

\section{a. Kebijakan K-13 PAUD : Peraturan Menteri Pendidikan dan Kebudayaan Republik Indonesia No. 146 Tahun 2014}

Lahirnya kurikulum 2013 PAUD merupakan cinta terindah dari Tuhan YME bagi bangsa dan anak-anak Indonesia. Sehingga jargon PAUD yang biasa kita kenal dengan " anak sehat, cerdas, ceria, mempunyai tambahan pada aspek karakter sesuai dengan salah satu latar belakang dari lahirnya K-13, sehingga menjadi "anak sehat, cerdas, ceria dan berbudi

\footnotetext{
2 Aninditya Sri Nugraheni, "Kebijakan Perubahan Kurikulum di Indonesia Ditinjau dari Sudut Pandang Mata Pelajaran Bahasa Indnesia”, Diskusi Ilmiah Dosen Tetap UIN Sunan Kalijaga Yogyakarta.

3 Yuliani Nurani, Implementasi Kurikulum 2013 Pendidikan Anak Usia Dini, (Jakarta : Yayasan Yebefo, 2015), hlm. 3.
} 
mulia”. Menurut penulis, sesungguhnya pembelajaran di PAUD sudah tematik dan terintegratif, akan tetapi untuk pendekatan integratif belum dipahami maknanya secara mendalam sehingga kebanyakan PAUD berjalan apa adanya dan masih banyak dari kalangan pendidik, akademisi dan orangtua yang lebih nyaman mengkonsumsi teori tanpa menganalisis lebih dalam dari pada memproduksinya sendiri. Selain itu, pemerintah berkewajiban untuk membuat acuan minimal pada kurikulum PAUD yang disebut dengan standar nasional.

Dewasa ini, menurut penulis standar nasional masih difahami sebagai standar yang mutlak sehingga memunculkan suatu sikap yang kurang etis terhadap kebijakan yang telah dibuat, misalnya standar tingkat pencapaian perkembangan anak (STPP) terdapat indikator yang sangat mudah atau terlalu sulit sehingga cenderung mengacuhkan dan tidak mempelajarinya lebih dalam. Oleh karena itu menurut penulis dalam kesempatan kali ini perlu memaparkan bahwa standar nasional merupakan acuan minimal dalam penyelenggaraan PAUD. ${ }^{4}$ Oleh karena sebagai acuan minimal maka setiap lembaga sekolah berhak mengembangkan dan menginovasikan kurikulum atau program pembelajaran semaksimal mungkin agar tujuan pembelajaran tercapai. Sebelum pemaparan kebijakan K-13 PAUD, tentunya perlu difahami makna dari PAUD itu sendiri.

Berdasarkan UU No. 20 tahun 2003 tentang sistem Pendidikan Nasional Bab I Pasal I Butir 14 menyatakan bahwa, PAUD merupakan suatu upaya pembinaan yang ditujukan kepada anak sejak lahir sampai usia 6 tahun yang dilakukan melaui rangsangan pendidikan untuk membantu pertumbuhan

4 Peraturan Menteri Pendidikan Nasional No. 58 Tahun 2009 tanggal 17 September 2009 tentang standar Pendidikan Anak Usia Dini, hlm. 1 
dan perkembangan jasmani dan rohani agar anak memiliki kesiapan belajar dalam memasuki pendidikan lebih lanjut. ${ }^{5}$ Undang-undang ini mengingatkan kepada masyarakat bahwa anak usia dini merupakan masa emas yang mudah distimulasi semua aspek perkembangan dan pertumbuhan anak. Selain itu, UU mengamanatkan bahwa pendidikan harus dipersiapkan secara terencana dan bersifat holistik yang melibatkan aspek pengasuhan, kesehatan, pendidikan dan perlindungan. Oleh karena itu memerlukan pendekatan pembelajaran yang mampu mengimplementasikan UU No. 20 tahun 2003, yaitu tematikintegratif. Hal ini sudah tertera dalam karakteristik K-13 PAUD yaitu menggunakan pembelajaran tematik dengan pendekatan saintifik dalam pemberian rangsangan pendidikan. Menggunakan penilaian autentik dalam memamtau perkembangan anak dan memberdayakan peran orangtua dalam proses pembelajaran serta mengoptimalkan perkembangan anak yang tercermin dalam kompetensi sikap, pengetahuan dan keterampilan. Selanjutnya landasan yuridis tentang peraturan Presiden No. 60 tahun 2013 tentang perkembangan anak usia dini yang holistik-integratif.

Dewasa ini dalam kebijakan pembelajaran tematik integratif selain landasan yuridis terdapat juga landasan filosofis dan psikologis. Dalam pembelajaran tematik integratif sangat dipengaruhi oleh tiga aliran filsafat, yaitu : progresivisme, konstrukstivisme dan humanisme. Aliran progresivisme memandang proses pembelajaran perlu ditekankan pada pembentukan kreativitas, jumlah kegiatan suasana yang natural dan memperhatikan pengalaman anak. Aliran konstruktivisme melihat pengalaman langsung anak sebagai kunci dalam

5 Undang-Undang No. 20 Tahun 2003 tentang sistem Pendidikan Nasional BAB I Pasal I Butir 14 . 
pembelajaran, sehingga pengetahuan merupakan hasil dari konstruksi atau bentukan manusia. Dalam artian pengetahuan tidak dapat ditransfer begitu saja tetapi harus diinterpretasikan sendiri oleh setiap anak. Sehingga proses belajar pada anak berkembang secara terus menerus yang dipengaruhi oleh sifat aktif anak dalam mengeksplorasi pengetahuan. Aliran humanism melihat anak dari keunikan/kekhasannya, potensinya atau motivasi yang dimilikinya. ${ }^{6}$

Landasan psikologis pada pembelajaran tematik integratif berkaitan dengan psikologi perkembangan peserta didik dan psikologis belajar. Psikologi perkembangan berfungsi untuk menentukan materi pembelajaran agar sesuai dengan tahap perkembangan anak. Sedangkan psikologi belajar memberikan kontribusi bagaimana pembelajaran dari materi yang telah ditentukan dapat tersampaikann kepada anak dan bagaimana anak mempelajarinya. ${ }^{7}$ Disimpulkan bahwa, landasan psikologis pada pembelajaran tematik integratif mempunyai peran yang urgen yaitu memperhatikan tahap perkembangan anak dan memperhatikan model pembelajaran pada anak dalam kegiatan belajar. Dari paparan landasan kurikulum K-13 PAUD ini, dalam implementasi pembelajaran Tematik integratif lebih intens menggunakan model pembelajaran berbasis masalah, proyek, discovery inquiri.

\section{b. Pembelajaran Berbasis K-13 PAUD}

Pendekatan Tematik Integratif merupakan pendekatan utama yang harus digunakan dalam pengembangan kegiatan

\footnotetext{
${ }^{6}$ Abdul Majid, Pembelajaran Tematik Terpadu, Cet. Ke II, (Bandung : PT. Remaja Rosdakarya, 2014), hlm.87-88.

7 Ibid., hlm. 88
} 
belajar melalui bermain utamanya untuk anak usia 3-4 tahun dan 4-6 tahun di berbagai lembaga PAUD. Hal ini dikarenakan pembelajaran akan disajikan dalam bentuk tema dalam pembelajaran terpadu dengan berbagai bidang aspek perkembangan yang terdiri dari aspek nilai moral dan agama, kognitif, sosial emosional, bahasa dan motorik dengan multidisiplier ilmu yang disebut dengan pendekatan integratif. Hal ini bertujuan untuk membangun anak-anak yang integratif yaitu matang secara aspek perkembangan anak dan mampu dalam berbagai ilmu atau sesuai dengan kecerdasannya masing-masing. Dalam ilmu praktisnya yaitu, anak mampu berkomunikasi dengan baik sama siapapun, bersikap baik atau mampu beradaptasi dan survive dengan lingkungan dimanapun berada atau disebut juga dengan teori fleksibilitas.

Pendekatan tematik integratif merupakan satu dari empat pendekatan dalam K-13 PAUD dengan uraian sebagai berikut. (1) Tematik integratif, (2) saintifik, (3) bermain kreatif, (4) kecerdasan jamak. Jikalau pendekatan tematik integratif dan saintifik menjadi sebuah keharusan dalam pengembangan kegiatan belajar karena anak usia dini tidak belajar mata pelajaran tertentu seperti matematika, sains dan bahasa secara terpisah. Hal ini atas berbagai kajian keilmuan PAUD bahwa anak belajar segala sesuatu dari fenomena dan objek yang ditemui. Ketika belajar tentang "AIR" mereka bisa belajar menghitung (matematika), mengenal sifat-sifat air (sains), menggambar air (kesenian) dan fungsi air dalam keluarga / lingkungan (pengetahuan sosial). ${ }^{8}$ Hal ini bisa dimaknai pembelajarannya terintegrasi pada disiplin

8 Slamet Suyanto, Dasar-dasar Pendidikan Anak Usia Dini, (Yogyakarta : HIkayat Publishing, 2005), hlm. 131. 
ilmu. Sedangkan pembelajaran dengan tema dasar tertentu dikenal dengan istilah tematik. Oleh karena itu, inilah salah satu bukti ilmiah bahwa pendekatan tematik integratif dijadikan pendekatan yang utama dalam pengembangan kegiatan belajar di PAUD.

Pendekatan bermain kreatif dan kecerdasan jamak sebagai salah satu alternatif sehingga dapat juga dipilih oleh pendidik dalam pengembangan kegiatan belajar melalui bermain. Tetapi, sebenarnya kedua pendekatan inilah yang menjadi khas bagaimana anak belajar dengan berbagai potensi kecerdasan yang berbeda satu dengan yang lainnya. ${ }^{9}$ Karena hanya sebagai alternatif kedua pendekatan ini boleh dikembangkan lebih lanjut atau tidak digunakan, karena pada hakikatnya pendekatan bermain banyak macamnya. Selain itu kurikulum dapat dikembangkan juga dengan pendekatan lain misalnya berbasis budaya lokal, berbasis multikultur, berwawasan agraris dll. Maknanya adalah tidak harus berbasis kecerdasan majemuk tetapi dapat dikembangkan sesuai potensi daerah dan kebutuhan pendidikan yang diselenggarakan. Akan tetapi menurut penulis, esensi dari bermain kreatif dan kecerdasan jamak tetap menjadi acuan dalam kegiatan pembelajaran dengan tidak menonjolkan secara tekstual tetapi terintegrasi secara langsung.

\section{c. Pengertian Tematik Integratif}

Konsep pembelajaran tematik merupakan pengembangan dari pemikiran dua tokoh pendidikan yaitu Jacob (1989) dengan konsep pembelajaran intedisipliner dan Fogarty (1991) dengan konsep pembelajaran terpadu. ${ }^{10}$ Pada program pendidikan

\footnotetext{
9 Yuliani Nuraini, Implementasi............., hlm. 3.

${ }^{10}$ Abdul Majid, Pembelajatan Tematik....., hlm. 85.
} 
pembelajaran terpaduyang dipilih dan dikembangkan yaitu, model keterhubungan (connected), yaitu model pembelajaran yang secara sengaja diusahakan untuk menghubungkan satu konsep dengan konsep lain, satu topik dengan topik lain, satu keterampilan dengan keterampilan lain dalam satu bidang studi. Tokoh yang mengembangkan ini adalah Robert Maynard Hutchins. Model jarring laba-laba (webbed) merupakan model pembelajaran terpadu menggunkan pendekatan tematik. Pengembangan pendekatan ini dimulai dari penentuan tema. Tema dapat ditetapkan dengan diskusi antara guru dan anak. Setelah tema disepakati kemudian mengembangkan sub tema dengan memperhatikan kaitannya dengan bidang studi atau bidang pengembangan anak. Kemudian mengembangkan kegatan belajar yang akan dilakukan oleh anak. Tokoh yang mengembangkan model ini yaitu Lydon B. Johnson. Model keterpaduan (integrated) merupakan model pembelajaran terpadu yang mengembangkan pendekatan antar bidang studi. Model ini diusahakan dengan cara menggabungkan bidang studi dengan cara menetapkan prioritas kurikuler dan menentukan keterampilan, konsep, sikap yang saling tumpang tindih di dalam beberapa bidang studi. Pertamakali pendidik menyeleksi konsep, keterampilan, sikap yang diajarkan dalam satu semester dari beberapa bidang studi selanjutnya pilih konsep keterampilan dan sikap yang memiliki hubungan yabg erat dan tumpang tindih antar berbagai bidang studi. Tokoh yang mengembangkan model ini adalah John Milton. ${ }^{11}$

Pada PAUD pembelajaran tematik lebih poluler digunakan dari pada pendekatan yang lainnya. Karena pembelajaran tematik merupakan suatu pendekatan dalam pembelajaran

$\overline{{ }^{11} \text { Ibid., hlm. 76-77. }}$ 
yang secara langsung mengaitkan beberapa aspek baik dalam satu konsep pembelajaran atau antar konsep pembelajaran. Dengan demikian anak akan memperoleh pengetahuan secara utuh sehingga pembelajaran bermakna. Bermakna artinya bahwa dalam pembelajran tematik anak akan dapat memahami konsep-konsep dasar yang mereka pelajari melalui pengalaman lagsung dan nyata yang menghubungkan konsep yang berdiri sendiri ataupun antar konsep pembelajaran. ${ }^{12}$ Selin itu menurut Purwadarmita (1983), pembelajaran tematik adalah pembelajaran terpadu yang menggunkan tema untuk mengaitkan beberapa mata pelajaran sehingga dapat memberikan pengalam bermakna kepada anak. Tema adalah pokok pikiran atau gagasan pokok yang menjadi pokok pembicaraan. ${ }^{13}$

Tematik integratif menurut Sangkot Sirait adalah suatu kegiatan pembelajaran dengan mengintegrasikan materi beberapa mata pelajaran pada dalam satu tema tertentu. pembelajaran tematik merupakan suatu upaya untuk mengintegrasikan pengetahuan, keterampilan, nilai atau sikap pembelajaran serta pemikiran yang kreatif menggunkan tema. Dari pandangan tersebut dapat dikatakan bahwa pembelajaran tematik integratif memiliki tujuan peningkatan kualitas pendidikan dan perbaikan pembelajaran yang lebih efisien khususnya pada padatnya materi pembelajaran dan kondisi kurikulum yang ada. ${ }^{14}$

Selanjutnya, tematik integratif menurut Andi Prastowo adalah pendekatan pembelajaran yang mengintegrasikan berbagai

\footnotetext{
12 Ibid., hlm. 85.

13 Ibid., hlm. 80.

${ }^{14}$ Sangkot Sirait, "Konsep Tematik Integratif dalam Pembelajaran MI, "Antologi Pendidikan Anak Usia Dini dan Pendidikan Dasar Islam”, Yogyakarta, jilid 2, Agustus 2015: 17 .
} 
kompetensi dari berbagai mata pelajaran ke dalam berbagai tema. Pengintegrasian ini merupakan usaha memadukan / mengntegrasikan aspek sikap, pengetahuan, keterampilan dan afektif menjadi kesatuan yang utuh pada setiap mata pelajaran atau kegiatan pembelajaran. ${ }^{15}$

Pada Pendidikan Anak Usia Dini pendekatan tematik integratif merupakan suatu pendekatan pembelajaran yang melibatkan beberapa bidang pengembangan untuk memberikan pengalaman yang bermakna kepada anak. Keterpaduan dalam pembelajaran ini dapat dilihat dari aspek proses, waktu atau kurikulum dan aspek belajar mengajar. Pembelajara tematik integratif diajarkan kepada anak karena pada umumnya anak masih melihat segala sesuatu sebagai keutuhan (holistic) karena perkembangan fisiknya tidak pernah dapat dipisahkan dengan perkembangan anak usia dini seperti perkembangan Nilai moral dan Agama, kognitif, bahasa, sosial emosional dan motorik. ${ }^{16}$

Tema merupakan pokok pikiran atau dasar cerita sedangkan tematik bersifat tema atau menjadi pokok pembicaraan. ${ }^{17}$ Oleh karena itu dapat diartikan bahwa tema adalah pokok pikiran yang menjadi dasar pembicaraan. Dalam pembelajaran di PAUD tema dapat diartikan sebagai suatu alat untuk mengepedankan berbagai konsep pembelajaran pada anak usia dini secara holistik. Tema diberadakan dengan tujuan menyatukan kurikulum dalam kesatuan yang utuh, memperkaya pengetahuan anak

${ }^{15}$ Andi Prastowo, Pengembangan Bahan Ajar Tematik, (Yogyakarta : Diva Press, 2013), hlm. 223.

${ }^{16}$ Yulianai Nuraini Sujiono \& Bambang Sujiono, Bermain Kreatif Berbasis Kecerdasan Jamak, (Jakarta “ PT . Indeks, 2010), hlm. 75.

${ }^{17}$ Indah Nuraini, Kamus Bahasa Indonesia, (Bogor : CV. Duta Grafika, 2010), hlm. 943. 
dan melibatkan beberapa kegiatan belajar untuk memperoleh pengalaman yang bermakna bagi anak. Integratif dalam kegiatan pembelajaran dapat dilihat dari aspek waktu, kurikulum dan aspek belajar mengajar. ${ }^{18}$

Disimpulkan bahwa pendekatan tematik integratif merupakan pendekatan pembelajaran yang mengintegrasikan sebagai potensi dari berbagai mata pelajaran ke dalam berbagai tema. Pengintegrasian tersebut disajikan dalam integrasi sikap spiritual, integrasi sosial, integrasi pengetahuan dan integrasi keterampilan dalam proses pembelajaran serta integrasi berbagai konsep dasar yang berkaitan. Ide pembelajaran bersifat tematik yang berkaitan dengan hal yang sangat dekat dengan anak dan hal yang paling jauh dengan anak.

\section{d. Pengembangan dan Pemilihan Tema}

Tema dapat dikembangkan secara fleksibel, sesuai dengan kebutuhan pekembangan anak agar tidak menimbulkan kebosanan. Menggunakan tema yang menarik bagi anak, sederhana, disesuaikan dengan lingkungan sekolah, serta disesuaikan dengan kebudayaan dan kepercayaan setempat. Pengembangan tema dapat dimulai dari hal yang paling dekat dengan kehidupan anak yaitu (diri sendiri) dan berkembang ke hal yang paling luas dan jauh dari kehidupan anak (semesta). ${ }^{19}$

Pemilihan tema didasari pada : (1) tema-tema yang bersifat dasar dan selalu dapat dikembangkan seperti, diri sendiri, sekolahku, rumahku, keluargaku, dan negeriku. (2), tema yang

\footnotetext{
${ }^{18}$ Yuliani Nuraini, Implementasi Kurikulum......, hlm. 5.

${ }^{19}$ Ika Budi Maryatun, Model Pembelajaran PAUD, 2011, http ://www.staff.uny. ac.id/sites/default/files/tmp/Model\%Pembelajaran\%PAUD.pdf (10 Mei 2015).
} 
dihubungkan dnegan suatu peristiwa / kejadian alam, misalnya cuaca alam, banjir, gunung meletus. (3) tema yang dihubungkan dengan minat anak, misalnya hobby, profesi, alam semesta. (4) tema yang di hubungkan dengan hari-hari besar atau spesial misalnya PHBI dan PHBN. Selain itu menurut Kostelnik (1991), tema juga dapat dikembangkan berdasarkan, (1) konsep sains berhubungan dengan tema tanaman dan binatang. (2), pengetahuan sosial seperti pakaian, rumah. (3), konsep matematika seperti berhitung, mengukur, pasar. (4), konsep bahasa dan seni yang berhubungan dengan musik, menulis, cerita. Oleh karena itu pendidik boleh memilih tema dan sub tema sesuai kesanggupan dalam menyediakan sarana dan prasarana yang dibutuhkan dalam kegiatan belajar. ${ }^{20}$

\section{e. Karakteristik Pengembangan Tema}

Karakteristik pengembangan Tematik Integratif, yaitu: (1) memperhatikan dan memahami karakteristik anak. Tema dikembangkan dengan memahami karakteristik anak, yaitu memahami banwa anak bersifat egosentris, anak memiliki rasa ingin tahu yang besar, anak adalah makhluk sosial, bersifat unik, memiliki daya konsentrasi yang pendek dan masa paling potensial untuk di stimulasi aspek perkembangannya. ${ }^{21}$ (2), Berpusat pada Anak. Pembelajaran tematik integratif yang berpusat pada anak (student centered) lebih sesuai jika diterapkan pada PAUD, karena menurut teori belajar modern konstruktivisme bahwa setiap

\footnotetext{
${ }^{20}$ Yuliani Nuraini Sujiono \& Bambang Sujiono, Bermain Kreatif Berbasis....., hlm. 76.

${ }^{21}$ Sofia Hartati, Perkembangan Belajar Anak Usia Dini, (Jakarta : Departemen Pendidikan Jenderal Pendidikan tinggi Direktorat Jenderal Pendidikan Tinggi Direktorat Pembinaan Pendidikan Tenaga Kependidikan Dan Ketenagaan Perguruan Tinggi Jakarta, 2005), hlm. 8-11.
} 
anak memiliki pengetahuan sendiri-sendiri. Oleh karena itu pendidik berperan penting sebagai fasilitator. (3), Memberikan Pengalaman Langsung. Pengalaman langsung dapat diperoleh anak dengan pembelajaran yang bermakna yaitu kongkrit sebagai dasar untuk memahami pegetahuan yang abstrak. Hal ini dapat dilakukan dengan cara menyediakan kesempatan pada anak untuk bereksplorasi dan terlibat langsung pada objek yang sesungguhnya. (4), Pemisahan bidang ilmu pengetahuan tidak begitu jelas. Kegiatan pembelajaran yang terintegrasi akan membuat anak belajar suatu konsep pembelajaran secara holistik dan spek perkembangannyapun akan berkembang secara holistic juga. Secara langsung anak belajar multidisiplin ilmu. (5), memberikan kegiatan dan rutinitas yang ditujukan untuk mengembangkan selurh aspek perkembangan, mengakomodasi kebutuhan fisik anak, (7) menggunakan prinsip belajar sambil bermain.

\section{f. Prosedur Pengembangan Tema}

Prosedur pengembangan tema di PAUD dapat dilakukan sebagai berikut : (1) Menentukan tema utama yang menjadi fokus pembelajaran. (2) menentukan dan membuat model tema dengan memperhatikan prinsip pemilihan tema yaitu yang terdekat dengan anak, nyata dan sederhana. (3) Membuat sub tema dan mengembangkannya. (4) yang berbeda dengan prosedur kali ini adalah terdapat pengembangan proyek tema. Menurut Nuraini, proyek tema atau disebut puncak tema adalah kegiatan yang dilakukan dalam siklus tertentu. Proyek tema dapat diselenggarakan di luar / di dalam sekolah. Proyek 
tema diselenggarakan setelah semua tema / sub tema disajikan dalam kegiatan pembelajaran melalui bermain. Misalnya minggu pertama sampai ketiga adalah penyajian tema / sub tema maka minggu ke empat adalah puncak tema. Tidak ada aturan yang terikat dalam merancang puncak tema akan diselenggarakan. Hal ini juga tergantung pada keluasan materi dan kesiapan guru. Tetapi disarankan puncak tema hendaknya melibatkan orangtua. ${ }^{22}$

\section{g. Rambu-Rambu Pembelajaran Tematik Integratif}

1. Tidak semua bidang pembelajaran dapat disatukan, misalnya PAI dapat berdiri sendiri jika terdapat kegiatan yang tidak dapat dipadukan.

2. Dimungkinkan terdapat penggabungan kompetensi dasar pada lintas semenster.

3. Kompetensi dasar yang tidak dapat diintegrasikan dapat berdiri sendiri.

4. Kompetensi dasar yang tidak tercangkup dalam tema pembelajaran dapat di ajarkan pada kegiatan mandiri.

5. Kegiatan pembelajaran ditekankan pada kemampuan membaca, menulis dan berhitung serta mengembangkan aspek lain.

6. Tema yang dipilih disesuaikan dengan karakteristik anak, dan lingkungan setempat. ${ }^{23}$

\footnotetext{
${ }^{22}$ Yuliani Nuraini, Implementasi kurikulum..., hlm. 14.

${ }^{23}$ Abdul Majid, Pembelajaran Tematik...., hlm. 91.
} 
62

\section{JURNAL AL-AFKAR}

Vol. III, No. 1, April 2015

h. Implementasi Pengembangan Tematik Integratif

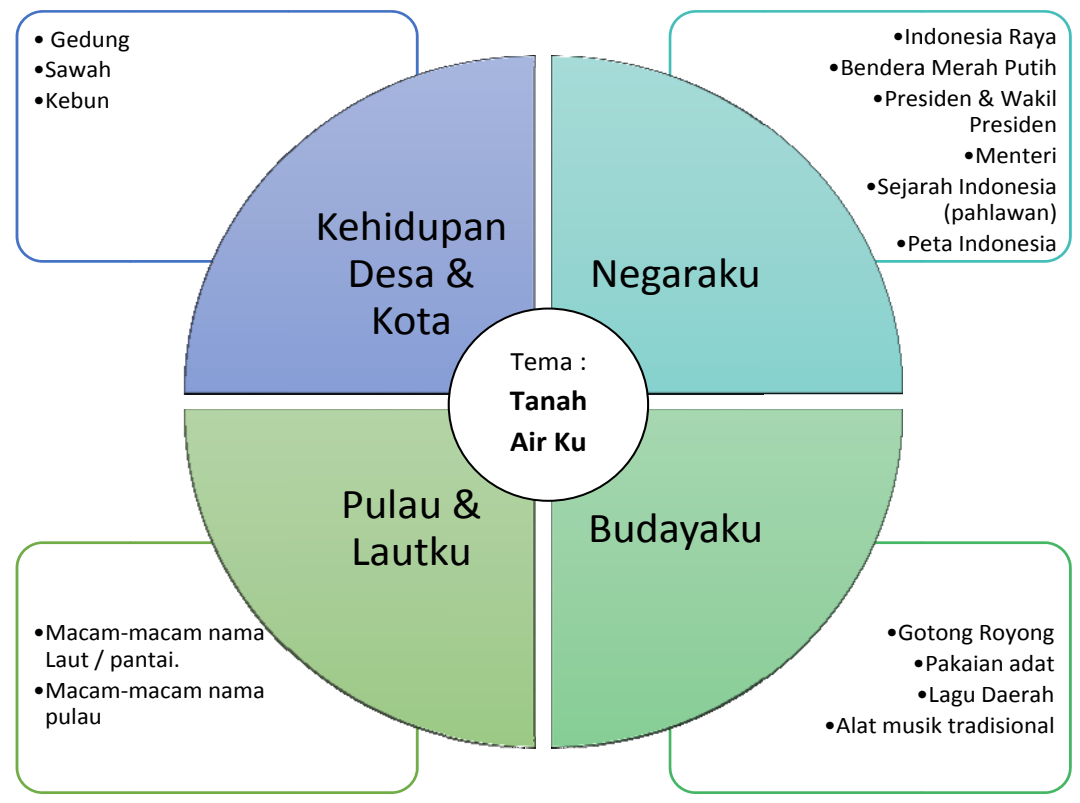

Gambar I. Pengembangan Tematik Integratif

Rencana Puncak Tema : Fashion show / carier day pakaian adat Perencanaan Pembelajaran

Penulis menawarkan perencanaan pembelajaran tematik integratif dengan langkah-langkah sebagai berikut :

1. Tentukan Tema dan subtema misalnya dalam (bulanan).

2. Memahami Kompetensi inti dan kompetensi dasar.

3. Membuat rencana kegiatan dalam satu bulan.

4. Membuat rencana crafting ( 4 kali dalam 1 bulan)

5. Menentukan lagu-lagu dalam 1 bulan (jawa, english, Indonesia, lagu daerah)

6. Rencana puncak tema. 


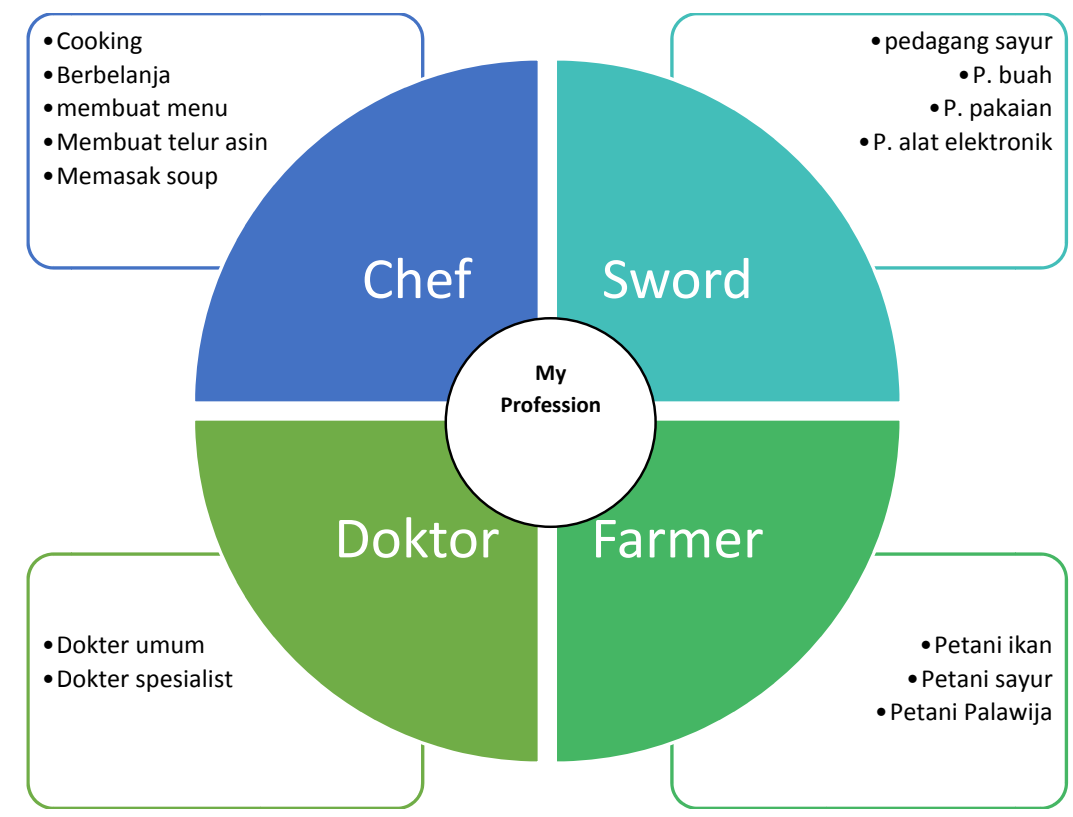

Gambar II. Pengembangan Tematik Integratif

Tabel I. Rencana Kegiatan Bulan Maret 2015

\begin{tabular}{|c|c|c|}
\hline MINGGU & HARI / TANGGAL & AGENDA \\
\hline I & Jum'at, 6 Maret 2015 & $\begin{array}{l}\text { « Upacara bendera (Lagu : maju tak gentar) } \\
\text { « Sunda Manda Profesi } \\
\text { « Pasaran (Jual-beli) } \\
\text { - Lotek (Batang pisang, tanah, botol } \\
\text { kecap, mangkok kecil, sendok bebek) } \\
\text { Mie ayam (irisan daun pisang, ros } \\
\text { pohon pisang, tanah, mangkuk kecil, } \\
\text { sendok bebek) } \\
\text { Sate (Batang pisang, tusuk sate, tanah, } \\
\text { mangkok kecil) } \\
\text { Aneka minuman (gelas plastik, sendok, } \\
\text { tempat agar-agar kecil, toples-toples, } \\
\text { kunyit, daun jati, kembang sepatu). } \\
\text { « Swimming }\end{array}$ \\
\hline
\end{tabular}




\section{4 \\ Vol. III, No. 1, April 2015}

\begin{tabular}{|c|c|c|}
\hline II & $\begin{array}{l}\text { Kamis, } 12 \text { Maret } 2015 \\
\text { Jum'at, } 13 \text { Maret } 2015 \\
9 \text { Maret - } 12 \text { Maret } 2015 \\
\text { (Assignment week) }\end{array}$ & $\begin{array}{l}\text { " Visit Library } \\
\text { " Movie Class "Upin-Ipin” (Cita-cita ku/ } \\
\text { Profesi) } \\
\text { « Make a box profession } \\
\text { " Membuat media tanam dari Koran bekas } \\
\text { " Mini Trip "Jalan-jalan di sekitar Kamulan } \\
\text { untuk melihat berbagai macam profesi ex. } \\
\text { Kantor pos, butik, pedagang, penjahit dll) } \\
\text { " MID Semester (Assignment week) }\end{array}$ \\
\hline III & $\begin{array}{l}\text { Senin, } 16 \text { Maret } 2015 \\
\text { Selasa, } 17 \text { Maret } 2015 \\
\text { Rabu, } 18 \text { Maret } 2015 \\
\text { Kamis, } 19 \text { Maret } 2015 \\
\text { Jum'at, } 20 \text { Maret } 2015\end{array}$ & $\begin{array}{l}\text { " Upacara (Lagu : Hipne guru) } \\
\text { " Menanam Sensivera dengan media tanam } \\
\text { Koran bekas } \\
\text { " Membuat permainan Tradisional "Tek- } \\
\text { tekan" } \\
\text { " Membuat air ajaib } \\
\text { " Stik Ajaib } \\
\text { " Membuat pelangi } \\
\text { " Career day (Setiap anak ditugaskan } \\
\text { membawa sayuran) } \\
\text { " Cooking Class "Soup" }\end{array}$ \\
\hline IV & $\begin{array}{l}\text { Senin, } 23 \text { Maret } 2015 \\
\text { Selasa, } 24 \text { Maret } 2015 \\
\text { Jum'at, } 27 \text { Maret } 2015\end{array}$ & $\begin{array}{l}\text { "Konservasi air } \\
\text { "Konservasi bilangan } \\
\text { "Eksplorasi Gamelan } \\
\text { « Story Telling Participation "Parent guest" }\end{array}$ \\
\hline
\end{tabular}


Tabel II. March Crafting

\begin{tabular}{|c|c|c|c|}
\hline No & Date & Crafting & Explanation \\
\hline 1. & Rabu, 4 Maret 2015 & Mini book profession & For children \\
\hline 2. & Kamis, 5 Maret 2015 & $\begin{array}{l}\text { Telur asin mainan dari dari } \\
\text { remasan Koran, dilabel dan } \\
\text { diberi angka / huruf } \\
\text { Besek kertas Koran (tempat } \\
\text { telur) }\end{array}$ & For school \\
\hline 3. & Senin, 9 Maret 2015 & $\begin{array}{l}\text { Crafting "make a box } \\
\text { profession" }\end{array}$ & For School \\
\hline 4. & Rabu, 11 Maret 2015 & $\begin{array}{l}\text { Crafting "menanam dengan } \\
\text { media jelly" }\end{array}$ & For Children \\
\hline 5. & Senin, 16 Maret 2015 & $\begin{array}{l}\text { Membuat berbagai karya dengan } \\
\text { bubur Koran }\end{array}$ & For School \\
\hline 6. & Selasa, 17 Maret 2015 & $\begin{array}{l}\text { Membuat permainan tradisional } \\
\text { "Tek-tek" }\end{array}$ & For Children \\
\hline 7. & Rabu, 14 Maret 2015 & Crafting "air ajaib” & For School \\
\hline 8. & Kamis, 26 Maret 2015 & $\begin{array}{l}\text { Crafting" Membuat mahkota } \\
\text { dari daun nangka / kertas" }\end{array}$ & For Children \\
\hline
\end{tabular}

\section{Tabel. III Songs of the month "March"}

\begin{tabular}{|l|l|}
\hline \multicolumn{1}{|c|}{ ten little Indians boys } & \multicolumn{1}{c|}{ Nenek Moyangku Orang Pelaut } \\
\hline $\begin{array}{l}\text { one little... } \\
\text { two little.. } \\
\text { three little Indians } \\
\text { four little.. }\end{array}$ & $\begin{array}{l}\text { Nenek moyangku orang pelaut } \\
\text { gemar mengarung luas samudra } \\
\text { five little.. } \\
\text { six little Indians } \\
\text { seven little... }\end{array}$ \\
eight little... & menempuh badai sudah biasa \\
nine little Indians & angin bertiup layar terkembang \\
ten little Indians boys & ombak berdebur di tepi pantai \\
& pemuda brani bangkit sekarang \\
& ke laut kita beramai-ramai \\
\hline
\end{tabular}




\begin{tabular}{|c|c|}
\hline Baa, baa, black sheep & Kidang Talun \\
\hline $\begin{array}{l}\text { Baa, baa, black sheep, have you any } \\
\text { wool? } \\
\text { Yes sir, yes sir, three bags full! } \\
\text { One for the master, } \\
\text { One for hodan, } \\
\text { And one for the little boy } \\
\text { Who lives down the lane } \\
\text { Baa, baa, black sheep, } \\
\text { Have you any wool? } \\
\text { Yes sir, yes sir, } \\
\text { Three bags full... }\end{array}$ & $\begin{array}{l}\text { Kidang ... Talun } \\
\text { Mangan kacang talun } \\
\text { Mil kethemil mil kethemil } \\
\text { Si kidang mangan lembayung } \\
\text { Tikus ... pithi } \\
\text { Due anak siji } \\
\text { Cit cit cuit } \\
\text { Cit cit cuit } \\
\text { Maju perang wani mati } \\
\text { Kidang ... Talun } \\
\text { Mangan kacang talun } \\
\text { Mil kethemil mil kethemil } \\
\text { Si kidang mangan lembayung } \\
\text { Gajah ... belang } \\
\text { Soko tanah mlembang } \\
\text { Nuk legunuk nuk legunuk } \\
\text { Gedhene meh podho gunung }\end{array}$ \\
\hline Five little friends & Profesi \\
\hline $\begin{array}{l}\text { Five little friends go tap tap tap } \\
\text { Five little friends go clap clap clap, } \\
\text { Five little friends go jump jump } \\
\text { jump, } \\
\text { Five little friends go bump, bump, } \\
\text { bump } \\
\text { Five little friend go round and round } \\
\text { Five little friends fall to the ground } \\
\text { (ect) }\end{array}$ & $\begin{array}{l}\text { Guru tugasnya mengajarkan ilmu } \\
\text { Dokter tugasnya mengobati orang sakit } \\
\text { Polisi tugasnya menegakkan hukum } \\
\text { Tentara tugasnya membela Negara } \\
\text { Petani kerjanyanya bercocok tanam } \\
\text { Perawat tugasnya merawat orang sakit } \\
\text { Penjahit kerjanya menjahit pakaian } \\
\text { Penyanyi kerjanya suka menyanyi } \\
\text { Kalau pilot menerbangkan pesawat terbang } \\
\text { Kalau masinis menjalankan kereta Api } \\
\text { Kalau Pak kusir menggendalikan delmannya } \\
\text { Kalau nahkoda mengemudikan kapalnya } \\
\text { Olahragawan kerjanya berolahraga } \\
\text { Kalau Wartawan tugasnya mencari berita } \\
\text { Kalau seniman kerjanya berkarya seni } \\
\text { Kalau ilmuwan ahlinya bidang keilmuan }\end{array}$ \\
\hline \multicolumn{2}{|l|}{ Sunday Monday song } \\
\hline $\begin{array}{l}\text { Sunday, Monday, Tuesday, } \\
\text { Wednesday,Thursday } \\
\text { Friday, saturday }\end{array}$ & \\
\hline
\end{tabular}

Rencana Puncak Tema : Carier Day " pedagan Sayur” \& cooking class "soup” 


\section{Penutup}

Kebijakan pembelajaran tematik integratif di PAUD berdasarkan pada peraturan menteri pendidikan dan kebudayaan Republik Indonesia No. 146 tahun 2014 tentang kurikulum 2013 PAUD. K-13 di kembangkan berdasarkan landasan yuridis, pdikologis dan filosofis. Pembelajaran berbasis K-13 PAUD, yaitu pendekatan tematik integratif merupakan pendekatan utama yang harus digunakan dalam pengembangan kegiatan belajar melalui bermain utamanya untuk anak usia 3-4 tahun dan 4-6 tahun di berbagai lembaga PAUD. Hal ini dikarenakan pembelajaran akan disajikan dalam bentuk tema dalam pembelajaran terpadu dengan berbagai bidang aspek perkembangan yang terdiri dari aspek nilai moral dan agama, kognitif, sosial emosional, bahasa dan motorik dengan multidisiplier ilmu yang disebut dengan pendekatan integratif. Dalam hal ini ada yang perlu digaris bawahi bahwa kebijakan yang dibuat dalam bentuk standar nasional merupakan acuan minimal dalam penggunaan K-13 PAUD, sehingga pendidik perlu mengembangkan sesuai kebutuhan dan potensi lingkungan setempat.

Pendekatan tematik integratif merupakan pendekatan pembelajaran yang mengintegrasikan sebagai potensi dari berbagai mata pelajaran ke dalam berbagai tema. Pengintegrasian tersebut disajikan dalam integrasi sikap spiritual, integrasi sosial, integrasi pengetahuan dan integrasi sikap dalam proses pembelajaran serta integrasi berbagai konsep dasar yang berkaitan. Ide pembelajaran bersifat tematik yang berkaitan dengan hal yang sangat dekat dengan anak dan hal yang paling jauh dengan anak.

Tema dapat dikembangkan secara fleksibel, sesuai dengan kebutuhan pekembangan anak agar tidak menimbulkan 


\section{8

kebosanan. Menggunakan tema yang menarik bagi anak, sederhana, disesuaikan dengan lingkungan sekolah, serta disesuaikan dengan kebudayaan dan kepercayaan setempat. Pengembangan tema dapat dimulai dari hal yang paling dekat dengan kehidupan anak yaitu (diri sendiri) dan berkembang ke hal yang paling luas dan jauh dari kehidupan anak (semesta). Sedangkan Pemilohan tema dapat di dasarkan pada konsep sains, matematika, bahasa dan seni.

Karakteristik pengembangan tema perlu memperhatikan karakteristik anak dan kegiatan pembelajaran pada anak. Prosedur pengembangan tema di PAUD dapat dilakukan sebagai berikut : (1) Menentukan tema utama yang menjadi fokus pembelajaran. (2) menentukan dan membuat model tema dengan memperhatikan prinsip pemilihan tema yaitu yang terdekat dengan anak, nyata dan sederhana. (3) Membuat sub tema dan mengembangkannya. (4) melakuka kegiatan puncak tema. Selain itu dalam pendekatan pembelajaran tematik integrative pendidik perlu memperhatikan rambu-rambu pembelajaran tematik integrative, karena terdapat pembelajaran yang hanya bisa berdiri sendiri. 


\section{DAFTAR PUSTAKA}

Budi Maryatun, Ika Model Pembelajaran PAUD, 2011, http : :/ www.staff.uny.ac.id/sites/default/files/tmp/ Model\%Pembelajaran\%PAUD.pdf Akses tanggal 10 Mei 2015

Hartati, Sofia, Perkembangan Belajar Anak Usia Dini, Jakarta: Departemen Pendidikan Jenderal Pendidikan tinggi Direktorat Jenderal Pendidikan Tinggi Direktorat Pembinaan Pendidikan Tenaga Kependidikan Dan Ketenagaan Perguruan Tinggi Jakarta, 2005.

Majid, Abdul, Pembelajaran Tematik Terpadu, Cet. Ke II, Bandung: PT. Remaja Rosdakarya, 2014.

Nuraini Sujion, Yuliani \& Bambang Sujiono, Bermain Kreatif Berbasis Kecerdasan Jamak, Yulianai Jakarta " PT . Indeks, 2010.

Nuraini, Indah, Kamus Bahasa Indonesia, Bogor : CV. Duta Grafika, 2010.

Nurani,Yuliani, Implementasi Kurikulum 2013 Pendidikan Anak Usia Dini, Jakarta : Yayasan Yebefo, 2015.

Peraturan Menteri Pendidikan Nasional No. 58 Tahun 2009 tanggal 17 September 2009 tentang standar Pendidikan Anak Usia Dini, hlm. 1

Prastowo, Andi, Pengembangan Bahan Ajar Tematik, Yogyakarta : Diva Press, 2013.

Sirait, Sangkot, "Konsep Tematik Integratif dalam Pembelajaran MI, "Antologi Pendidikan Anak Usia Dini dan Pendidikan Dasar Islam”, Yogyakarta, jilid 2, Agustus 2015. 
70

\section{JURNAL AL-AFKAR}

Vol. III, No. 1, April 2015

Sri Nugraheni, Aninditya, "Kebijakan Perubahan Kurikulum di Indonesia Ditinjau dari Sudut Pandang Mata Pelajaran Bahasa Indnesia”, Diskusi Ilmiah Dosen Tetap UIN Sunan Kalijaga Yogyakarta, Mei 2015.

Suyanto, Slamet, Dasar-dasar Pendidikan Anak Usia Dini, Yogyakarta: HIkayat Publishing, 2005.

Undang-Undang No. 20 Tahun 2003 tentang sistem Pendidikan Nasional.

Undang-Undang No. 20 Tahun 2003 tentang sistem Pendidikan Nasional Bab I Pasal I Butir 14. 